\title{
Co-culture of early cattle embryos to the blastocyst stage with oviducal tissue or in conditioned medium*
}

\author{
W. H. Eyestone and N. L. First \\ Department of Meat and Animal Science, University of Wisconsin, Madison, WI 53706, USA
}

\begin{abstract}
Summary. In Exp. 1, 5-8-cell embryos from superovulated cattle were co-cultured with oviducal tissue suspended in Ham's F10 + 10\% fetal calf serum (F10FCS) or in F10FCS alone. After 4 days, the proportion of embryos developing into compact morulae or blastocysts was greater $(P<0.005)$ in co-culture $(38 / 82 ; 46 \%)$ than in F10FCS $(1 / 27 ; 4 \%)$. In Exp. 2, a solution of collagenase, trypsin, DNAse and EDTA was used to disperse oviducal tissue, which was then cultured in TCM199+10\% fetal calf serum (M199FCS) to obtain monolayers. Embryos (1-8 cells) were then co-cultured with monolayers or in M199FCS alone. The proportion of embryos developing into compact morulae and blastocysts after $4-5$ days was higher $(P<0.005)$ in co-culture $(15 / 34 ; 43 \%)$ than in M199FCS $(1 / 37 ; 3 \%)$; mean numbers of cells/embryo were also higher $(P<0.001)(27.70$; range $2-82$ in co-culture; 8.83 ; range $2-18$ in M199FCS). In Exp. 3, embryos obtained from in-vitro maturation and fertilization were used to compare development between co-culture and medium conditioned by oviducal tissue. Initial cleavage rate (no. embryos $>1$ cell/total) was $76 \%(611 / 807)$ and did not differ among treatments. After 5 days, the proportion cleaving to $>16$ cells was higher $(P<0.005)$ in co-culture $(71 / 203 ; 35 \%)$ and conditioned medium $(48 / 205$; $23 \%$ ) compared to M199FCS $(14 / 203 ; 7 \%)$. Similarly, the proportion developing into compact morulae and blastocysts was greater $(P<0.005)$ in co-culture $(44 / 203 ; 22 \%)$ and conditioned medium $(46 / 205 ; 22 \%)$ than in M199FCS $(7 / 203 ; 3 \%)$. Developmental potential was tested in Exp. 4 by transferring embryos to 11 recipients, of which 6 $(55 \%)$ became pregnant.
\end{abstract}

Keywords: embryo; co-culture; cattle; in vitro; oviduct

\section{Introduction}

Conventional culture systems have proved inadequate for the culture of cattle embryos from early cleavage to the blastocyst stage (reviewed by Wright \& Bondioli, 1981). Part of this culture problem stems from the existence of a block to in-vitro culture at the 8-16-cell stage (Thibault, 1966; Camous et al., 1984; Heyman et al., 1987). Attempts to improve existing culture systems by modifying compositional or physical parameters have failed to yield consistent results. However, the failure of in-vitro culture systems to support early development may be alleviated in some species by co-culturing embryos with oviducal tissue. For example, Biggers et al. (1962) reported that mouse embryos developed past the '2-cell block' when co-cultured with oviducts. More recently, oviducal cell monolayers have been shown to enhance the development of sheep embryos in vitro (Gandolfi \& Moor, 1987; Rexroad \& Powell, 1988). The aim of the present work was to examine the effect of oviducal tissue co-culture on the development of cattle embryos in vitro. Some of the results have appeared in abstract form (Eyestone et al., 1987a).

*Reprint requests to Dr N. L. First. 


\section{Materials and Methods}

\section{Isolation of oviducal tissue}

Oviducts were obtained from cattle at slaughter (Exps 1 and 2) or by salpingectomy (Exps 3 and 4), trimmed free of connective tissue and rinsed in $0.9 \%(\mathrm{w} / \mathrm{v}) \mathrm{NaCl}$ containing $100 \mathrm{IU}$ penicillin $/ \mathrm{ml}, 100 \mu \mathrm{g}$ streptomycin/ml and $0.25 \mu \mathrm{g}$ amphotericin $\mathrm{B} / \mathrm{ml}$. After blotting on sterile gauze to remove excess fluid and blood, oviducts were placed in sterile $100-\mathrm{mm}$ Petri dishes, grasped with a forceps at the isthmic end and scraped gently toward the infundibulum with a glass microscope slide. Mucosal tissue was then extruded from the ostium abdominale and transferred to a $12-\mathrm{ml}$ conical tube with $10 \mathrm{ml}$ TALP-Hepes medium (low bicarbonate TALP; Parrish et al., 1988). Tissue was then washed in 5-7 changes of TALP-Hepes medium.

Experiment 1. After washing, the tissue pellet was resuspended in Ham's F10 supplemented with $10 \%$ heat-treated fetal calf serum and $50 \mu \mathrm{l}$ gentamicin/ml (F10FCS) in a ratio of one oviduct equivalent:50 ml F10FCS. The tissue suspension was cultured in 24-well culture plates $\left(1 \mathrm{ml}\right.$ suspension/well) at $37^{\circ} \mathrm{C}$ in a humidified atmosphere of $5 \%$ $\mathrm{CO}_{2}$ in air. Oviduct cultures were established 2-18 days before embryo co-culture. Embryos (5-8 cells), obtained from superovulated beef heifers killed 3 days after oestrus, were randomly assigned to co-culture with oviduct tissue or culture in F10FCS alone. After 4 days (equivalent to Day 7 after oestrus), embryos were evaluated for development to the compact morula or blastocyst stage. The number of nuclei per embryo was determined in one replicate by staining with Hoechst 33342 (Pursel et al., 1985).

Experiment 2. After washing, oviducal tissue was dispersed in a triple enzyme solution containing 200 units collagenase/ml (type V: Sigma, St Louis, MO, USA), $0 \cdot 1 \%(w / v)$ trypsin (Sigma, type II) and 80 units deoxyribonuclease/ml (Sigma, type II). Enzymes were dissolved in phosphate-buffered saline $(0.05 \mathrm{M}, \mathrm{pH} 7 \cdot 3$ ) containing $0.2 \mathrm{mg}$ ethylenediaminetetra-acetic acid $/ \mathrm{ml}$. Tissue was incubated in the enzyme solution for $45 \mathrm{~min}$ at $4{ }^{\circ} \mathrm{C}$, then at $39^{\circ} \mathrm{C}$ for an additional $45 \mathrm{~min}$. Disaggregated tissue was washed 3 times in $10 \mathrm{ml}$ medium 199 supplemented with $10 \%$ heattreated fetal calf serum and $50 \mu \mathrm{g}$ gentamicin $/ \mathrm{ml}$ (M199FCS). Cells were then suspended in $0.2 \%$ trypan blue and counted on a haemocytometer; final cell concentration was adjusted to $1 \times 10^{6}$ live (trypan blue-negative) cells $/ \mathrm{ml}$. The final suspension was then added to wells of 96-well culture plates at a density of $1 \times 10^{6}$ cells/cm $\mathrm{cm}^{2}$ Culture conditions were identical to those in Exp. 1. Monolayers ( $70-100 \%$ confluent) formed within $48 \mathrm{~h}$, at which time the original medium was replaced with $150 \mu \mathrm{l}$ fresh M199FCS. Control wells were prepared at this time by adding $150 \mu \mathrm{l}$ M199FCS to fresh wells. Oviduct cultures were started 1-8 days before embryo co-culture. Embryos (1-8 cells) were obtained from superovulated beef heifers salpingectomized 2-3 days after oestrus and randomly assigned to co-culture on monolayers or culture in M199FCS alone. All embryos were assessed for development as in Exp. 1.

Experiment 3. Washed oviducal tissue was resuspended in M199FCS to a ratio of 1:50 (v/v); $5 \mathrm{ml}$ suspension were placed in $50 \mathrm{ml}$ culture flasks and cultured for 1-7 days. All cultures in this experiment were conducted at $39^{\circ} \mathrm{C}$. Media were replenished every 2-3 days by replacing $50 \%$ of the total volume with fresh M199FCS. Embryos were obtained by in-vitro maturation (Sirard et al., 1988) and in-vitro fertilization (Parrish et al., 1986). Ova were removed from fertilization droplets after 18-22 h, stripped of cumulus cells by repeated pipetting through a small-bore pipette, and assigned randomly to culture in M199FCS alone (control), tissue suspension (co-culture) or in medium conditioned by oviduct tissue. Conditioned medium was prepared from the supernatant after centrifugation of the tissue suspension at $13000 \mathrm{~g}$ for $10 \mathrm{~min}$. All culture treatments were conducted in $50 \mu \mathrm{l}$ droplets under paraffin oil ( $40-90 \mathrm{embryos} /$ droplet). The following details were recorded: (1) fertilization rate, determined by sampling $10-15$ ova from each replicate $18-22 \mathrm{~h}$ after insemination, fixing in ethanol-acetic acid $(3: 1, \mathrm{v} / \mathrm{v})$, staining with aceto-orcein and examining at $\times 400$ with phase-contrast microscopy for the presence of two pronuclei and a sperm tail; (2) cleavage rate, or number cleaved to $>1$ cell/total, determined by examination under a dissecting microscope at $\times 100$ magnification at $42-48 \mathrm{~h}$ after insemination; (3) number with $>16$ cells/number cleaved (cell number based on nuclear counts after staining with Hoechst 33342 as in Exp. 1); and (4) number of compact morulae and blastocysts/number cleaved. The last two observations were obtained $144 \mathrm{~h}$ after insemination.

Experiment 4. Embryos were generated by in-vitro maturation and fertilization and cultured with oviducal tissue or in conditioned medium as in Exp. 3. Late morulae and blastocysts were transferred non-surgically to recipient heifers 5-7 days after oestrus (1-2 embryos/uterine horn). Pregnancy was determined by rectal palpation 45 to 60 days after oestrus.

\section{Results}

\section{Experiment 1}

Oviducal tissue suspensions underwent striking morphological changes during the first few days of culture. Initially, tissue fragments took the form of sheet-like rafts, often moving about the culture dish due to ciliary activity. This was a prominent feature of cultured oviducal tissue and 
gave the cultures a very lively appearance. Within 24-36 h most of these rafts formed epithelial vesicles, accumulated fluid and, like the rafts, moved about the dish under ciliary propulsion. Isolated cells and tissue fragments attached to the culture plate after 2-5 days, and formed confluent monolayers after 5-7 days. Ciliary activity in epithelial vesicles and in monolayers diminished after $1-2$ weeks.

Co-culture of 5- to 8-cell embryos with oviducal tissue suspensions increased $(P<0.005)$ the proportion developing to the compact morula or blastocyst stages compared to culture of embryos in F10FCS alone $(38 / 82(46 \%)$ versus $1 / 27(4 \%)$, respectively; data from 5 replicates). Similarly, the mean nuclei number/embryo was higher $(P<0.001)$ after co-culture than after culture in FIOFCS, at least in the one replicate in which this measure was examined. In addition, most of the blastocysts present on Day 7 expanded by Day 10; however, none hatched from the zona pellucida.

\section{Experiment 2}

Confluent monolayers formed within $48 \mathrm{~h}$ after enzymic tissue dispersion. Preliminary experiments (data not shown) indicated that monolayers (75-100\% confluence) formed within 2 days in M199FCS compared to 5-7 days in F10FCS. Therefore, M199FCS was chosen for use in Exps 2, 3 and 4. Monolayers consisted primarily of ciliated and non-ciliated epithelial cells. Ciliary activity continued for about 1 week, diminished during the 2 nd week and was almost non-existent by the 3 rd week.

Oviduct cells in monolayer culture improved the proportion of embryos cleaving past 16 cells as well as the proportion developing further compared to culture in M199FCS (Table 1). Mean numbers of nuclei per embryo were also greater for co-cultured embryos relative to M199FCS controls.

Table 1. Co-culture of 1-8-cell cow embryos with oviducal cell monolayers*

\begin{tabular}{|c|c|c|c|c|}
\hline Treatment & $\begin{array}{c}>16 \text { cells / total } \\
(\%)\end{array}$ & $\begin{array}{c}\text { Compact morula } \\
+ \text { blastocysts } / \\
\text { total }(\%)\end{array}$ & $\begin{array}{c}\text { Mean no. of } \\
\text { nuclei/embryo }\end{array}$ & (range) \\
\hline Co-culture & $22 / 35(63)^{\mathrm{a}}$ & $15 / 35(43)^{c}$ & $27 \cdot 70^{e}$ & $(2-82)$ \\
\hline M199FCS & $2 / 37(5)^{b}$ & $1 / 37(3)^{d}$ & $8 \cdot 83^{f}$ & $(2-18)$ \\
\hline
\end{tabular}

*Data from 9 replicates: ${ }^{\text {a.b;c,d } P<0.005 ; ~}{ }^{\text {e,f }} P<0.001$.

\section{Experiment 3}

Oviducal tissue behaved in a manner similar to that described in Exp. 1, except that isolated attachment to the culture flask was often observed after 12-24 h and confluent monolayers formed within 3 days. Monolayers, once formed, underwent changes similar to those described in Exp. 2.

Overall fertilization rate was $88 \%$ (43/49). Mean cleavage rate was $76 \%(611 / 807)$ and did not vary among culture treatments (Table 2). The proportion of embryos that cleaved to $>16$ cells was higher in co-culture and conditioned medium compared to M199FCS. In addition, the proportion of $>16$ cell embryos was higher in co-culture than in conditioned medium. However, the proportion of embryos developing to the compact morula or blastocyst stages was similar in co-culture and conditioned medium and higher than in M199FCS control.

\section{Experiment 4}

A total of $6 / 11(55 \%)$ recipients became pregnant after embryo transfer ( $2 / 5$ from co-culture; $4 / 6$ from conditioned medium) and 5 normal healthy calves were obtained. Blastocysts not 
Table 2. Development of in-vitro matured, in-vitro fertilized embryos in co-culture with oviducal tissue or in conditioned medium*

\begin{tabular}{lccc}
\hline Treatment & $\begin{array}{c}>\text { cell/total } \\
(\%)\end{array}$ & $\begin{array}{c}>16 \text { cells/no. }>1 \text { cell } \\
(\%)\end{array}$ & $\begin{array}{c}\text { Compact morula }+ \\
\text { blastocyst/no. }>1 \text { cell } \\
(\%)\end{array}$ \\
\hline $\begin{array}{l}\text { Co-culture } \\
\text { Conditioned } \\
\text { medium }\end{array}$ & $203 / 275(74)$ & $71 / 203(35)^{\mathrm{a}}$ & $44 / 203(22)^{\mathrm{a}}$ \\
M199FCS & $205 / 266(77)$ & $48 / 205(23)^{\mathrm{ab}}$ & $46 / 205(22)^{\mathrm{a}}$ \\
\hline
\end{tabular}

*Data from 4 replicates. All comparisons are within columns.

${ }^{\mathrm{a} . \mathrm{b}} P<0.05 ;{ }^{\mathrm{a}, \mathrm{c}} P<0.005$.

transferred were co-cultured for an additional 6-7 days. During this period, most $(13 / 18 ; 72 \%)$ expanded and hatched in vitro by Day 11 after insemination.

\section{Discussion}

Co-culture of early cattle embryos with oviducal tissue enhanced development compared to culture in medium alone. This result was achieved with both oviducal tissue suspensions and cell monolayers, and with embryos obtained in vivo as well as by in-vitro maturation and fertilization. Furthermore, medium conditioned by oviduct tissue was as effective as co-culture in supporting development to the compact morulae and blastocyst stages. Morulae and blastocysts produced in co-culture or conditioned medium were developmentally competent since calves were obtained after transfer to recipient cattle. Embryos held for up to 14 days in co-culture or conditioned medium hatched and grew in a manner similar to that observed in vivo.

The proportion of embryos that developed normally in co-culture or conditioned medium compares favourably to results obtained after in-vivo culture in xenogenous oviducts. For example, the percentage of normal embryos obtained after co-culture (42-46\%; Exps 1 and 2) was similar to that achieved in ligated sheep oviducts (37-53\%; Eyestone et al., 1987b). Moreover, the proportion of normal embryos obtained after co-culture approached that obtained from superovulated cattle on Days 6-8 after oestrus (53\%; Massey \& Oden, 1984). For maturation and fertilization in vitro, the percentages of normal embryos obtained after co-culture $(22 \%$; Table 2$)$ or culture in conditioned medium (22\%; Table 2) fell within the range obtained after culture in ligated sheep oviducts (20-28\%; Sirard et al., 1988). Furthermore, the developmental potential of morulae and blastocysts thus obtained was similar to that of Day 6-8 embryos collected from superovulated cattle as judged by pregnancy rates achieved after transfer to recipients $(55 \%$; Exp. 4 versus $51 \%$, Massey \& Oden, 1984).

Oviducal tissue has been successfully used as a supplement to in-vitro embryo culture in a variety of species. In mice, 1-cell ova cleaved past the 2-cell block to the morula and blastocyst stages when incubated in cultured mouse oviducts (Biggers et al., 1962; Whittingham \& Biggers, 1967). Using a similar technique, Minami et al. (1988) cultured hamster embryos through the 2-cell block to morulae and blastocysts. Among the large domestic species, early sheep embryos have been cultured past the 8-16-cell block to the blastocyst stage on oviducal cell monolayers (Gandolfi \& Moor, 1987). Development on oviducal monolayers was superior to that on fibroblast monolayers or in medium alone, suggesting that the effect was tissue-specific. This notion is supported by the results of Rexroad \& Powell (1988) who found that culture of sheep embryos for 1-3 days on oviducal monolayers, but not with kidney or uterine tissue, improved development to Day 8 after transfer to the uterus. 
The means by which oviducal tissue supports early development in vitro are unknown. Possible mechanisms include the addition of embryotrophic factors to the medium, or the removal of substances inhibitory to development. The former hypothesis is supported by the results of Heyman et al. (1987) who demonstrated the existence of a low-molecular weight $(<2700)$ peptide in embryotrophic fractions of medium conditioned by trophoblastic vesicles. Oviducal secretory proteins have been described for a number of species (mouse: Kapur \& Johnson, 1985, 1986; rabbit: Oliphant et al., 1984; sheep: Sutton et al., 1984; cow: Roberts et al., 1975; baboon: Fazleabas \& Verhage, 1986; human: Edwards, 1980). Furthermore, oviducal cell monolayers, capable of supporting development of sheep zygotes to the blastocyst stage in vitro, appear to secrete some of the same proteins found in oviducal fluid (Gandolfi \& Moor, 1988). Many of these authors have suggested that such proteins play a regulatory role in early development, although in no case has this been demonstrated experimentally. Indirect support for the possibility that co-culture acted by removing inhibitory substances stems from the demonstration of inhibitory compounds in the formulae of media commonly used for embryo culture (reviewed by Wright \& Bondioli, 1981). For example, Loutradis et al. (1987) found that hypoxanthine in Ham's F-10 medium induced a 2-cell block in mouse embryos, and pyruvate, as a component of modified Kreb's-Ringer bicarbonate solution, was found to be inhibitory to development of early pig embryos (Davis \& Day, 1978). Both hypoxanthine and pyruvate may be metabolized by the co-cultured tissue, thereby reducing their concentrations to account for the beneficial effects observed on development. Neither substance, however, is known to inhibit development of early cattle embryos.

Due to their simplicity, co-culture systems such as the ones described here offer an attractive alternative to in-vivo culture in the ligated oviducts of sheep or rabbits. The efficacy of oviductconditioned medium is particularly important in that it will permit studies on early development without the confounding effects of in-vivo culture or the presence of co-cultured tissue. Moreover, elucidation of the mechanism underlying the positive influence of co-culture may lead to the development of defined media for cattle embryos.

We thank Jenifer Vignieri for technical assistance, David Northey and Valerie Schutzkus for animal care, Brad Haley for abattoir material and Julie Busby for manuscript preparation. This research was supported by the College of Agricultural and Life Sciences, USDA Grant 85-CRCR-1-1801 and W. R. Grace and Company.

\section{References}

Biggers, J.D., Gwatkin, R.B.L. \& Brinster, R.L. (1962) Development of mouse embryos in organ culture of fallopian tubes on a chemically defined medium. Nature, Lond. 194, 747-749.

Camous, S., Heyman, Y., Meziou, W. \& Menezo, Y. (1984) Cleavage beyond the block stage and survival after transfer of early bovine embryos cultured with trophoblastic vesicles. J. Reprod. Fert. 72, 479-485.

Davis, D.L. \& Day, B.N. (1978) Cleavage and blastocyst formation by pig eggs in vitro. J. Anim. Sci. 46, 1043-1053.

Edwards, R.C. (1980) The female reproductive tract. In Conception in the Human Female, pp. 416-524. Academic Press, London.

Eyestone, W.H., Vignieri, J. \& First, N.L. (1987a) Co-culture of early bovine embryos with oviductal epithelium. Theriogenology 27, 228, Abstr.

Eyestone, W.H., Leibfried-Rutledge, M.L., Northey, D.L., Gilligan, B.G. \& First, N.L. (1987b) Culture of one- and two-cell bovine embryos to the blastocyst stage in the ovine oviduct. Theriogenology 28, $1-7$.
Fazleabas, A.T. \& Verhage, H.G. (1986) The detection of oviduct-specific proteins in the baboon (Papio anubis). Biol. Reprod. 35, 455-462.

Gandolfi, F. \& Moor, R.M. (1987) Stimulation of early development in the sheep by co-culture with oviduct epithelial cells. J. Reprod. Fert. 81, 23-28.

Gandolf, F. \& Moor, R.M. (1988) Interactions between somatic and germinal cells during early development. Proc. Ilth Int. Congr. Anim. Reprod. \& I.A., Dublin, Vol. 5, pp. 169-176.

Heyman, Y., Menezo, Y., Chesne, P., Camous, S. \& Garnier, V. (1987) In vitro cleavage of bovine and ovine early embryos: improved development using co-culture with trophoblastic vesicles. Theriogenology 27, 59-68.

Kapur, R.P. \& Johnson, L.V. (1985) An oviductal fluid glycoprotein associated with ovulated mouse ova and early embryos. Devl Biol. 112, 89-93.

Kapur, R.P. \& Johnson, L.V. (1986) Selective sequistration of an oviductal fluid glycoprotein in the perivitelline space of mouse oocytes and embryos. $J$. exp. Zool. 238, 249-260.

Downloaded from Bioscientifica.com at 04/26/2023 12:44:09PM 
Loutradis, D., John, D. \& Kiessling, A.A. (1987) Hypoxanthine causes a 2-cell block in random-bred mouse embryos. Biol. Reprod. 37, 311-316.

Massey, J.M. \& Oden, A.J. (1984) No seasonal effect on embryo donor performance in the southwest region of the USA. Theriogenology 21, 196-217.

Minami, N., Bavister, B.D. \& Iritani, I. (1988) Development of hamster two-cell embryos in the isolated mouse oviduct in organ culture system. Gamete Res. 19, 235-240.

Oliphant, G., Reynolds, A.B., Smith, P.F., Ross, P.R. \& Marta, J.S. (1984) Immunocytochemical localization and determination of hormone-induced synthesis of sulfated oviductal glycoproteins. Biol. Reprod. 31, 165-174.

Parrish, J.J., Susko-Parrish, J.L., Leibfried-Rutledge, M.L., Critser, E.S., Eyestone, w.H. \& First, N.L. (1986) Bovine in vitro fertilization with frozenthawed semen. Theriogenology 25, 591-600.

Parrish, J.J., Susko-Parrish, J.L., Winer, M.A. \& First, N.L. (1988) Capacitation of bovine sperm by heparin. Biol. Reprod. 38, 1171-1180.

Pursel, V.G., Wall, R.J., Rexroad, C.E., Jr, Hammer, R.E. \& Brinster, R.L. (1985) A rapid whole-mount staining products for nuclei of mammalian eggs. Theriogenology 24, 687-691.
Rexroad, C.E., Jr \& Powell, A.M. (1988) Co-culture of ovine ova with oviductal cells in medium 199. $J$. Anim. Sci. 66, 947-953.

Roberts, G.P., Parker, J.M. \& Symonds, H.W. (1975) Proteins from the luminal fluid of the oviduct. $J$. Reprod. Fert. 45, 301-313.

Sirard, M.A., Parrish, J.J., Ware, C.B., LeibfriedRutledge, M.L. \& First, N.L. (1988) The culture of bovine oocytes to obtain developmentally competent embryos. Biol. Reprod. 39, 546-552.

Sutton, R., Nancarrow, C.D., Wallace, A.L.C. \& Rigby, N.W. (1984) Identification of an oestrus-associated glycoprotein in oviductal fluid of the sheep. $J$. Reprod. Fert. 72, 415-422.

Thibault, C. (1966) La culture in vitro de l'ouef de vache. Annls Biol. anim. Biochem. Biophys. 6, 159-164.

Whittingham, D.G. \& Biggers, J.D. (1967) Fallopian tube and early cleavage in the mouse. Nature, Lond. 213, 942-943.

Wright, R.W., Jr \& Bondioli, K.R. (1981) Aspects of in vitro fertilization and embryo culture in domestic animals. J. Anim. Sci. 53, 702-729.

Received 1 September 1988 